\title{
Effect of Diabetes Condition on Topical Treatment of Binahong Leaf Fraction in Wound Healing Process
}

\section{Pengaruh Kondisi Diabetes pada Pemberian Topikal Fraksi Daun Binahong dalam Proses Penyembuhan Luka}

\author{
Kintoko $^{1^{*}}$, Hanifah Karimatulhajj ${ }^{2}$, Trie Yuni Elfasyari², Ersi Arviana Ihsan ${ }^{2}$, Teguh Adiyas Putra ${ }^{2}$, \\ Puspawan Hariadi ${ }^{2}$, Citra Ariani ${ }^{1}$, Nurkhasanah ${ }^{1}$ \\ ${ }^{1}$ Fakultas Farmasi, Universitas Ahmad Dahlan. Yogyakarta \\ ${ }^{2}$ Pascasarjana Farmasi, Universitas Ahmad Dahlan, Yogyakarta
}

\begin{abstract}
Diabetes mellitus (DM) is a metabolic disease which is becoming the first number of health problem in Indonesia, based on the results of the Basic Health Research of Ministry of Health in 2013. One of the diabetes complications affected by high levels of blood glucose is diabetic ulcers wich $85 \%$ the number of cases was overed by amputation as the result of improper handling. Herbal treatments could be an alternative treatment of diabetic ulcers, one of them is binahong plant. The results of previous studies have shown the ability of ethanolic extract of binahong leaf in accelerating wound healing in diabetic rats. This study would be a continued study to test five kinds of binahong leaf fractions (FDB) with gradual solvent polarity in accelerating wound healing in diabetic ulcer. Wound healing parameters observed were percentage of wound healing from the wound diameter contraction. The test begins with ethanolic extract of binahong leaf fractionation to produce fractions of hexane (FHDB), chloroform (FKDB), ethyl acetate (FEADB), and ethanol (FEDB). Water fraction (FADB) was obtained from ethanolic leaf extract residues of binahong leaf extraction. Each fraction activity was tested topically twice daily on dorsal of test animals that created wounds using a punch biopsy $5 \mathrm{~mm}$ diameters. Grouping of test animals were divided into 13 groups with normal control group (non diabetes), negative control (diabetes + topical application of biocream $₫$ ), positive control (diabetes + topical application of madecassol), and 10 diabetes groups with topical application of 5 kinds of binahong leaf fractions with each fractions consist of a concentrations of $5 \%$ and $10 \%$ with biocream $₫$ as a vehicle. Diabetic parameters measured include blood glucose levels (KGD) and weight lost percentage ( $P B_{\%}$ ) in day 1 and 10 during a 10-day treatment. The results showed the influence of KGD in the condition of diabetes on wound healing rats diabetic ulcers which topically treated with binahong leaf fractions. FADB $10 \%$ has significant differences potention in wound healing process in diabetic rats macroscopically that accelerates wound contraction compared with negative and positive control groups $(p<0,05)$.
\end{abstract}

Keywords: Wound Healing; Diabetes; Binahong; Blood Glucose Level; Body Weight

\begin{abstract}
ABSTRAK
Diabetes mellitus (DM) merupakan penyakit metabolik yang menjadi problem kesehatan nomor $1 \mathrm{di}$ Indonesia berdasarkan hasil Riset Kesehatan Dasar Kementrian Kesehatan tahun 2013. Salah satu komplikasi akibat DM adalah luka diabetes akibat tingginya kadar glukosa darah dengan jumlah $85 \%$ kasus yang berakhir dengan amputasi akibat penanganan yang kurang tepat. Pengobatan herbal dapat menjadi alternatif pengobatan luka diabetes, salah satunya ialah tanaman binahong. Hasil penelitian sebelumnya menunjukkan kemampuan ekstrak etanolik daun binahong dalam mempercepat penyembuhan luka diabetes. Penelitian ini menjadi penelitian lanjutan untuk menguji 5 jenis fraksi daun binahong menggunakan pelarut dengan tingkat polaritas yang berbeda dalam penyembuhan luka diabetes. Parameter kesembuhan luka yang diamati berupa persentase penyembuhan luka dari pengecilan diameter luka. Uji diawali dengan fraksinasi ekstrak etanolik daun binahong menghasilkan fraksi heksan (FHDB), fraksi kloroform (FKDB), fraksi etil asetat (FEADB), dan fraksi etanol (FEDB). Fraksi air (FADB) didapat dari residu maserasi ekstrak etanolik daun binahong. Masing-masing fraksi diuji aktivitasnya secara topikal $2 x$ sehari pada punggung hewan uji yang dibuat luka dengan punch biopsy berdiameter $5 \mathrm{~mm}$. Pengelompokkan hewan uji dibagi menjadi 13 kelompok dengan kelompok kontrol normal (non diabetes), kontrol negatif (diabetes + aplikasi topikal
\end{abstract}

Correspondence author: Kintoko

Email : kkintoko77@gmail.com 
biocream $($ )), kontrol positif (diabetes + aplikasi topikal madecassol), dan 10 kelompok diabetes dengan aplikasi topikal 5 jenis fraksi daun binahong dengan konsentrasi masing-masing 5\% dan 10\% dengan biocream $\circledR$ sebagai pembawa. Parameter diabetes yang diukur meliputi kadar glukosa darah (KGD) dan persentase penyusutan berat badan (PB\%) di hari ke 1 dan 10 selama perlakuan. Hasil penelitian menunjukkan adanya pengaruh KGD pada kondisi diabetes terhadap penyembuhan luka tikus diabetes yang diberi fraksi daun binahong. FADB 10\% memiliki potensi yang signifikan dalam penyembuhan luka dengan mempercepat penutupan luka tikus pada kondisi diabetes secara makroskopis dibandingkan dengan kelompok kontrol negatif dan positif $(p<0,05)$.

Kata kunci: Wound healing; Diabetes; Binahong; Kadar Glukosa Darah; Berat Badan

\section{PENDAHULUAN}

Penyakit diabetes mellitus (DM) ditandai dengan meningkatnya kadar glukosa dalam darah akibat adanya gangguan metabolisme glukosa dalam tubuh. Organ pankreas penderita DM memiliki kelemahan dalam memproduksi hormon insulin. Akibatnya, distribusi glukosa darah ke organ tubuh lainnya terhambat sehingga kadar glukosa dalam darah meningkat (Zychowska et al., 2013). Komplikasi luka diabetes pada penderita DM cukup banyak ditemukan di Indonesia, yang termasuk dalam 10 besar negara dengan pengidap DM terbanyak yang mencapai 8,5 juta jiwa (Anonim, 2014).

Kadar glukosa darah yang tinggi di dalam darah menyebabkan penderita DM mengalami penyembuhan luka yang lebih lama dibanding dengan manusia normal. Hal ini karena luka pada kondisi DM termasuk dalam luka kronis (Nagori and Solanki, 2011) akibat perpanjangan fase penyembuhan luka yaitu haemostasis, inflamasi, proliferasi, dan remodeling (Enoch and Leaper, 2008). Penanganan yang tidak tepat pada luka kronis pada DM akan mengakibatkan infeksi yang umumnya diatasi dengan amputasi (Jeffcoate and Harding, 2003; Karri et al., 2015). Oleh karena itu, perlu adanya alternatif dalam perawatan luka diabetes yang dapat dilakukan dengan tanaman obat (Leung, 2007).

Tanaman binahong (Anredera cordifolia (Tenore) Steen) dari suku Basellaceae memiliki pengaruh dalam mempercepat penyembuhan luka kulit dilihat dari efek proliferasi sel (Takahashi et al., 2012). Pemberian daun segar tanaman binahong yang dihaluskan pada luka kelinci dapat mempercepat penyembuhan luka (Ariani, 2014). Ekstrak etanoliknya juga dapat mempercepat proses penutupan luka pada luka diabetes tikus yang diinduksi aloksan (Kintoko and Desmayanti, 2016). Ekstrak etanolik daun binahong masih memiliki kandungan kimia yang kompleks sehingga perlu dilakukan penelitian lanjutan dengan proses fraksinasi untuk melihat pengaruh setiap fraksi dalam proses penyembuhan luka pada kondisi diabetes dengan parameter diabetes berupa kadar glukosa darah dan berat badan. Penelitian ini menggunakan senyawa diabetogenik streptozotocin (STZ) yang dapat merusak sel $\beta$ pankreas secara permanen (IslasAndrade et al., 2001).

\section{METODODOLOGI Bahan dan alat}

Daun binahong (Anredera cordifolia (Tenore) Steen) yang didapat dari tanaman obat EMPAT F Kota Yogyakarta dan dideterminasi di Laboratorium Biologi Universitas Ahmad Dahlan (UAD) Yogyakarta, biocream ${ }^{\circledR} \quad\left(\right.$ Merck $\left.^{\circledR}\right)$, madecassol ${ }^{\circledR}\left(\right.$ Corsa $\left.^{\circledR}\right)$, streptozotocin (Nacalai tesque $^{\circledR}$ ), ketamin injeksi $\left(\right.$ Generik $\left.^{\circledR}\right)$, reagen GOD FS $\left(\right.$ Diasys $\left.^{\circledR}\right)$. Hewan uji tikus jantan galur Wistar usia 2 bulan dengan rentang berat badan 150-180 g yang didapat dari Universitas Sanatadarma (USD) Yogyakarta.

\section{Penyiapan Fraksi}

Fraksinasi diawali dengan pembuatan ekstrak etanolik daun binahong dengan pelarut etanol $96 \%$ dan diekstraksi dengan metode maserasi. Maserat dipekatkan dengan Rotary vaccum evaporator dengan suhu $50^{\circ}$ C. Residu hasil maserasi (serbuk) dikeringkan dan dilarutkan dalam aquadest dan diinfundasi untuk mendapat fraksi air (FADB). Ekstrak etanolik pekat difraksinasi menggunakan 4 pelarut dengan metode fraksinasi cair-padat sederhana menggunakan mortir. Fraksinasi dilakukan sebanyak 3 kali dengan masing-masing pelarut sebanyak $200 \mathrm{~mL}$. Pertama dengan pelarut heksan yang menghasilkan fraksi heksan (FHDB) yang kemudian dipekatkan. Residu yang tak larut heksan dikeringkan kemudian difraksinasi menggunakan kloroform, etil asetat, dan etanol dengan cara yang sama hingga didapat fraksi kloroform (FKDB), fraksi etil asetat (FEADB), dan fraksi etanol (FEDB). Fraksi pekat yang didapat kemudian ditimbang dengan bobot tertentu dan dicampurkan dengan basis (biocream ${ }^{\circledR}$ ) hingga konsentrasi tiap fraksi menjadi $5 \%$ dan $10 \%$. Metode ini berdasar review dari jurnal Sasidharan et al. (2011) dan Najafi (2013) dengan modifikasi.

\section{Penyiapan Hewan Uji}

Hewan uji sebanyak 42 tikus dimasukkan ke dalam kandang individu untuk aklimatisasi selama 7 hari sebelum perlakuan. Suhu kandang 
dijaga 24 C dan siklus pencahayaan ruangan dengan 12 jam gelap-terang. Pemberian pakan dilakukan 2 kali sehari dengan pemberian jenis pakan ayam Bangkok AD II. Pemberian minum dilakukan sehari sekali sebanyak $150 \mathrm{~mL}$ dengan air mineral. Semua perlakuan terhadap hewan uji telah mendapatkan persetujuan etik dari Komite Etik Penelitian Universitas Ahmad Dahlan (KEP UAD) Yogyakarta (no: 011606129).

\section{Induksi Diabetes dengan Streptozotocin (STZ)}

Streptozotocin (STZ) dilarutkan dalam larutan buffer sitrat dingin $(2,5 \mathrm{~mL} / \mathrm{kgBB}$ tikus $)$ dengan $\mathrm{pH} 4,5$. Induksi STZ dilakukan segera setelah pembuatan larutan dengan dosis tunggal $45 \mathrm{mg} / \mathrm{kgBB}$ i.p. Setelah diinduksi, tikus diberikan pakan dan minum ad libitum. Metode ini berdasar penelitian Ghasemi et al. (2014) dengan modifikasi.

\section{Pengamatan Parameter Diabetes Pemeriksaan Kadar Glukosa Darah}

Pemeriksaan kadar glukosa darah (KGD) puasa dilakukan sebelum induksi STZ, 3 hari setelah induksi STZ (Nayak et al., 2007), dan 2x selama perlakuan pada hari ke 1 dan 10 pemberian aplikasi topikal 5 jenis fraksi daun binahong. Darah tikus diambil dari retro orbital plexus dengan menggunakan pipa kapiler melalui dinding eppendorf. Setelah 30 menit, darah disentrifugasi selama 20 menit dengan kecepatan $8000 \mathrm{rpm}$ pada suhu $25 \mathrm{C}$ untuk mendapatkan serum darah (Srinivasan et al., 2005). Penetapan kadar glukosa berdasarkan kit penetapan kadar glukosa metode GOD-PAP (fotometri) dari DiaSys.

\section{Penimbangan Berat Badan (BB) Hewan Uji}

Berat badan hewan uji ditimbang pada hari ke 1 dan 10 selama perlakuan sebagai parameter diabetes dan untuk mengetahui persentase penyusutan berat badan dengan perhitungan sebagai berikut:

$P B_{\%}=\frac{B B_{10}-B B_{1}}{B B_{1}} \times 100 \%$

Keterangan: $\mathrm{PB} \%=$ persentase penyusutan berat badan;

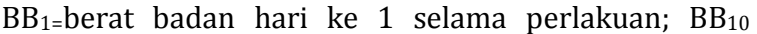
=berat badan hari ke 10 selama perlakuan

\section{Pembuatan Luka pada Hewan Uji}

Setelah 3 hari pasca induksi STZ dosis tunggal $45 \mathrm{mg} / \mathrm{kgBB}$, hewan uji dengan KGD di atas $200 \mathrm{mg} / \mathrm{dL}$ digunakan untuk perlakuan hewan uji diabetes. Selanjutnya dilakukan pembuatan luka yang diawali dengan anestesi hewan uji dengan ketamin dosis $50 \mathrm{mg} / \mathrm{kgBB}$ i.m. Setelah hewan uji kehilangan kesadaran, area punggung kanan dan kiri dibuat luka eksisi menggunakan punch biopsy berdiameter $5 \mathrm{~mm}$ (Romero-Cerecero et al., 2014).

\section{Pengelompokan Hewan Uji}

Perlakuan pada hewan uji tikus dibagi menjadi 13 kelompok, dengan 1 kelompok non diabetes dan 12 kelompok diabetes yaitu kontrol normal: non diabetes, tanpa pemberian obat, kontrol negatif: diabetes + aplikasi topikal biocream $\AA$, kontrol positif : diabetes + aplikasi topikal madecasol, dan kelompok 10 Fraksi : diabetes + aplikasi topikal fraksi. Perlakuan dilakukan 2x sehari setiap 12 jam, pagi dan sore sebanyak $\pm 25 \mathrm{mg}$ di area luka dan sekitarnya. Kelompok fraksi daun binahong yaitu fraksi heksan (FHDB), fraksi kloroform (FKDB), fraksi etil asetat (FEADB), fraksi etanol (FEDB), dan fraksi air (FADB) masing-masing dengan 2 konsentrasi (5\% dan 10\%) dibuat dengan basis biocream $\AA$. Pemberian aplikasi topikal dilakukan selama 10 hari setelah pembuatan luka.

\section{Persentase Penutupan Luka (PL\%)}

Persentase penutupan luka dihitung dengan rumus:

$$
\mathrm{PL} \%=\frac{d o-d n}{d o} \times 100 \%
$$

Keterangan: $d_{o}=$ diameter luka awal; $d_{n}=$ diameter luka pada hari pengamatan

Diameter didapat dari rata-rata dua area luka punggung kanan dan kiri (Vidinskỳ et al., 2006) dengan mengukur 4 sisi diameter luka dengan jangka sorong (Morton and Malone, 1972) dan dari. Pengukuran diameter luka dilakukan pada sore hari.

\section{Analisis Data}

Data yang diperoleh dari hasil pengamatan tersebut dianalisis secara statistik menggunakan program SPSS 16 dengan taraf kepercayaan $(\mathrm{P}=95 \%)$. Analisis diawali dengan uji normalitas dan uji homogenitas dan dilanjutkan dengan uji One way Anova. Jika data normal dan homogen $(p$ $>0,05)$, analisis dilanjutkan dengan post-hoc LSD. Jika data tidak normal atau tidak homogen, analisis dilakukan dengan uji non parametrik. Perbedaan bermakna jika signifikansi kurang dari taraf kesalahan $\alpha(\mathrm{p}<0,05)$ (Mappa et al., 2013).

\section{HASIL DAN PEMBAHASAN}

\section{Hasil Fraksinasi}

Ekstrak etanolik daun binahong didapat dari serbuk daun binahong kering dengan total rendemen 25.81\%. Masing-masing FHDB, FKDB, 
Tabel I. Parameter diabetes kadar glukosa darah (KGD) dan berat badan (BB) selama 10 hari perlakuan pemberian topikal 5 jenis fraksi daun binahong yang diukur pada hari ke 1 dan 10

\begin{tabular}{ccccccc}
\hline Kelompok & $\begin{array}{c}\text { KGD H-1 } \\
\text { mg/dL }\end{array}$ & $\begin{array}{c}\text { KGD H-10 } \\
\text { mg/dL }\end{array}$ & $\begin{array}{c}\text { Perubahan } \\
\text { KGD mg/dL }\end{array}$ & $\begin{array}{c}\text { BB H-1 } \\
\text { (gram) }\end{array}$ & $\begin{array}{c}\text { BB H-10 } \\
\text { (gram) }\end{array}$ & $\begin{array}{c}\text { Penyusutan } \\
\text { BB (\%) }\end{array}$ \\
\hline Kontrol normal & $71,82 \pm 2,12$ & $68,98 \pm 15,31$ & $-2,84 \pm 17,04$ & $190,33 \pm 28,11$ & $205,67 \pm 26,50$ & $8,35 \pm 5,16$ \\
Kontrol negatif & $292,80 \pm 11,58^{*}$ & $195,09 \pm 116,72$ & $-97,71 \pm 110,93$ & $168,33 \pm 17,16$ & $144,00 \pm 9,85^{*}$ & $-14,08 \pm 7,38^{*}$ \\
Kontrol positif & $290,09 \pm 7,21^{*}$ & $312,06 \pm 12,57^{*} \#$ & $21,97 \pm 18,04^{\#}$ & $165,67 \pm 34,08$ & $158,00 \pm 29,51$ & $-4,39 \pm 2,33^{*}$ \\
FHDB5\% & $290,67 \pm 8,29^{*}$ & $284,10 \pm 8,23^{*} €$ & $-6,56 \pm 5,90^{\ddagger}$ & $198,00 \pm 29,44$ & $181,00 \pm 26,06$ & $-8,34 \pm 8,39^{*}$ \\
FHDB10\% & $286,23 \pm 15,55^{*}$ & $222,34 \pm 103,13^{*} €$ & $-63,89 \pm 90,20^{€}$ & $186,33 \pm 18,72$ & $182,33 \pm 8,08^{\#}$ & $-1,45 \pm 11,10$ \\
FKDB5\% & $296,56 \pm 53,86^{*}$ & $213,45 \pm 110,30^{*}$ & $-83,11 \pm 163,52$ & $178,33 \pm 8,33$ & $160,00 \pm 44,40$ & $-9,36 \pm 29,81$ \\
FKDB10\% & $300,78 \pm 43,46^{*}$ & $232,47 \pm 70,59^{*}$ & $-68,31 \pm 30,61^{*} €$ & $196,33 \pm 15,70^{\#}$ & $184,67 \pm 9,50^{\#}$ & $-5,79 \pm 3,20^{*}$ \\
FEADB5\% & $300,29 \pm 4,05^{*}$ & $311,11 \pm 2,39^{*} \#$ & $10,82 \pm 1,85^{*} \#$ & $194,33 \pm 20,60$ & $177,00 \pm 23,43$ & $-9,08 \pm 3,75^{*}$ \\
FEADB10\% & $299,75 \pm 5,02^{*}$ & $307,27 \pm 1,72^{*} \#$ & $7,52 \pm 3,72^{\#}$ & $188,00 \pm 38,43$ & $166,67 \pm 27,15$ & $-10,84 \pm 4,70^{*}$ \\
FEDB5\% & $300,13 \pm 2,80^{*}$ & $303,68 \pm 7,20^{*}$ & $3,55 \pm 5,07^{\#}$ & $145,67 \pm 7,51$ & $148,00 \pm 16,37$ & $1,54 \pm 8,71$ \\
FEDB10\% & $298,03 \pm 9,76^{*}$ & $247,92 \pm 104,45^{*}$ & $-50,11 \pm 108,09$ & $197,67 \pm 28,57^{*}$ & $162,67 \pm 28,92^{*}$ & $-17,91 \pm 3,89^{*} €$ \\
FADB5\% & $287,57 \pm 6,74^{*}$ & $257,38 \pm 46,58^{*} €$ & $-30,20 \pm 45,87 €$ & $193,00 \pm 16,52$ & $175,33 \pm 17,01^{\#}$ & $-9,21 \pm 1,05^{*} €$ \\
FADB10\% & $290,47 \pm 9,33^{*}$ & $294,29 \pm 9,06^{*}$ & $3,83 \pm 2,29 \#$ & $168,00 \pm 3,61$ & $150,00 \pm 13,08^{*}$ & $-10,62 \pm 9,20^{*}$ \\
\hline
\end{tabular}

Kelompok perlakuan: kontrol normal (non diabetes), kontrol negatif (diabetes + aplikasi topikal biocream ${ }^{\circledR}$ ), kontrol positif (diabetes + aplikasi topikal madecassol), aplikasi topikal 5 jenis fraksi daun binahong: FHDB (fraksi heksan), FKDB (fraksi kloroform), FEADB (fraksi etil asetat), FEDB (fraksi etanol), FADB (fraksi air) konsentrasi 5\% dan 10\% dengan basis biocream ${ }^{\circledR}$. ${ }^{*} \mathrm{p}<0,05$ dibandingkan dengan kontrol normal, ${ }^{*} \mathrm{p}<0,05$ dibandingkan dengan kontrol negatif, $\epsilon_{\mathrm{p}}<0,05$ dibandingkan dengan kontrol positif. Data ditulis dalam $\overline{\mathrm{x}} \pm \mathrm{SD}(\mathrm{n}=3)$

FEADB, dan FEDB didapat sebesar 16.44\%; 5.064\%; 2.23\%; dan 77.67\% dari ekstrak etanolik. Sedangkan FADB sebesar 0,128 \% dari residu hasil maserasi.

\section{Hasil Pengamatan Parameter Diabetes}

Induksi STZ dosis tunggal $45 \mathrm{mg} / \mathrm{kgBB}$ menyebabkan peningkatan kadar glukosa darah (KGD) hingga di atas $200 \mathrm{mg} / \mathrm{dL}$ akibat terjadinya kerusakan sel $\beta$ pankreas sehingga sintesis insulin terganggu (Ghasemi et al., 2014). Diabetes merupakan kondisi hiperglikemia dengan KGD yang diukur setelah puasa yaitu bernilai 150 mg/dL (Furman, 2015) dengan adanya gejala polyfagia, polydypsia, dan polyurea (Kolluru et al., 2012; Patel et al., 2012). Induksi STZ menyebabkan terjadinya DM tipe 1 yang ditandai dengan penyusutan berat badan (Wang et al., 2014). Tabel I menunjukkan parameter diabetes berupa kadar glukosa darah (KGD) dan berat badan (BB) pada hari ke 1 dan 10 selama perlakuan.

KGD hewan uji pada hari ke 1 perlakuan pada seluruh kelompok diabetes lebih tinggi dan berbeda signifikan dengan hewan uji non diabetes. Hal tersebut menunjukkan terjadinya diabetes. Selama 10 hari perlakuan terjadi perubahan KGD pada hewan uji, baik peningkatan maupun penurunan KGD. Di hari ke 10, hanya KGD kelompok kontrol negatif yang berbeda tidak signifikan dengan kelompok normal yaitu bernilai
195,09 $\pm 116,72 \mathrm{mg} / \mathrm{dL}$. Nilai tersebut memiliki simpangan yang besar karena terjadi variasi yang besar pada hewan uji dalam kelompok tersebut. Hal ini dapat terjadi karena setiap hewan uji memiliki respon yang berbeda terhadap induksi STZ yang dipengaruhi oleh imunitas hewan uji, sehingga hewan uji dapat menghasilkan insulin yang akan menurunkan KGD.

Peningkatan KGD yang signifikan selama 10 hari perlakuan dibandingkan dengan kelompok kontrol negatif terjadi pada kelompok kontrol positif, FEADB 5\%, FEADB 10\%, dan FADB 10\%. Keempat kelompok tersebut mengalami peningkatan KGD masing-masing sebesar $21,97 \pm 18,04 ; \quad 10,82 \pm 1,85 ; \quad 7,52 \pm 3,72$; $3,55 \pm 5,07$; dan $3,83 \pm 2,29 \mathrm{mg} / \mathrm{dL}$ sehingga $\mathrm{KGD}$ masing-masing bernilai 312,06 $\pm 12,57$; $311,11 \pm 2,39 ; \quad 307,27 \pm 1,72 ; \quad 303,68 \pm 7,20 ; \quad$ dan $294,29 \pm 9,06 \mathrm{mg} / \mathrm{dL}$. Penurunan KGD yang signifikan dibandingkan dengan kelompok kontrol positif terjadi pada kelompok FHDB 5\%, FHDB 10\%, FKDB 10\%, dan FADB 5\% dengan penurunan KGD masing-masing $-6,56 \pm 5,90$; $63,89 \pm 90,20 ; \quad-68,31 \pm 30,61$; dan $-30,20 \pm 45,87$ $\mathrm{mg} / \mathrm{dL}$. Nilai KGD hari ke 10 masing-masing kelompok tersebut ialah 284,10 $\pm 8,23$; $222,34 \pm 103,13 ; 232,47 \pm 70,59$; dan $257,38 \pm 46,58$ $\mathrm{mg} / \mathrm{dL}$. Terjadinya penyusutan berat badan pada sebagian besar kelompok diabetes yang terlihat dari nilai negatif menunjukkan terjadinya DM tipe 1. 
Tabel II. Pengaruh perubahan KGD dan BB pada kondisi diabetes terhadap penyembuhan luka secara makroskopis

\begin{tabular}{cccc}
\hline Kelompok Hewan Uji & $\begin{array}{c}\text { Perubahan KGD } \\
\text { mg/dL }\end{array}$ & PB $\%$ & $\begin{array}{c}\text { PL } \% \\
\text { Hari ke-10 }\end{array}$ \\
\hline Kontrol normal & $-2,84 \pm 17,04$ & $8,35 \pm 5,16$ & $54,17 \pm 19,09$ \\
Kontrol negatif & $-97,71 \pm 110,93$ & $-14,08 \pm 7,38^{*}$ & $57,48 \pm 2,75$ \\
Kontrol positif & $21,97 \pm 18,04$ & $-4,39 \pm 2,33^{*}$ & $53,33 \pm 5,77$ \\
FHDB 5\% & $-6,56 \pm 5,90^{€}$ & $-8,34 \pm 8,39^{*}$ & $52,16 \pm 4,15$ \\
FHDB 10\% & $-63,89 \pm 90,20^{€}$ & $-1,45 \pm 11,10$ & $67,14 \pm 6,23^{\# €}$ \\
FKDB 5\% & $-83,11 \pm 163,52$ & $-9,36 \pm 29,81$ & $54,17 \pm 4,17$ \\
FKDB 10\% & $-68,31 \pm 30,61^{€}$ & $-5,79 \pm 3,20^{*}$ & $64,86 \pm 4,08^{\#} €$ \\
FEADB 5\% & $10,82 \pm 1,85$ & $-9,08 \pm 3,75^{*}$ & $52,10 \pm 8,09$ \\
FEADB 10\% & $7,52 \pm 3,72$ & $-10,84 \pm 4,70^{*}$ & $53,71 \pm 3,21$ \\
FEDB 5\% & $3,55 \pm 5,07$ & $1,54 \pm 8,71$ & $50,24 \pm 15,94$ \\
FEDB 10\% & $-50,11 \pm 108,09$ & $-17,91 \pm 3,89^{*} €$ & $52,63 \pm 7,19$ \\
FADB 5\% & $-30,20 \pm 45,87 €$ & $-9,21 \pm 1,05^{*} €$ & $58,81 \pm 11,21$ \\
FADB 10\% & $3,83 \pm 2,29$ & $-10,62 \pm 9,20^{*}$ & $69,34 \pm 6,35^{\#} €$ \\
\hline
\end{tabular}

Kelompok perlakuan: kontrol normal (non diabetes), kontrol negatif (diabetes + aplikasi topikal biocream®), kontrol positif (diabetes + aplikasi topikal madecassol), aplikasi topikal 5 jenis fraksi daun binahong: FHDB (fraksi heksan), FKDB (fraksi kloroform), FEADB (fraksi etil asetat), FEDB (fraksi etanol), FADB (fraksi air) konsentrasi 5\% dan 10\% dengan basis biocream ${ }^{\circledR}$. " $\mathrm{p}<0,05$ dibandingkan dengan kontrol normal, ${ }^{*} \mathrm{p}<0,05$ dibandingkan dengan kontrol negatif, $\epsilon_{\mathrm{p}}<0,05$ dibandingkan dengan kontrol positif. Data ditulis dalam $\overline{\mathrm{x}} \pm \mathrm{SD}(\mathrm{n}=3)$

\section{Pengaruh Parameter Diabetes (KGD dan berat} badan) terhadap Proses Penyembuhan Luka

Percepatan penyembuhan luka pada kondisi diabetes dapat dilakukan dengan kontrol glukosa darah (Kolluru et al., 2012). Penurunan KGD pada kelompok FHDB 10\% dan FKDB10\% berperan dalam mempercepat penutupan luka. Sebaliknya, peningkatan KGD pada kelompok kontrol positif, FEADB 5\%, FEADB 10\%, dan FEDB $5 \%$ yang berbeda signifikan dengan kontol negatif memperlambat penutupan luka. Namun, kelompok FADB $10 \%$ yang mengalami peningkatan KGD justru mengalami percepatan penutupan luka. Hal ini menunjukkan bahwa FADB 10\% memiliki potensi yang lebih baik dalam penyembuhan luka dibanding FHDB 10\% dan FKDB 10\% yang mengalami penurunan KGD.

Penyusutan BB pada kondisi DM tipe I secara tidak langsung berkaitan dengan penyembuhan luka. Berat badan yang rendah pada kondisi DM menunjukkan rendahnya trigliserida yang tersimpan dalam tubuh sebagai akibat adanya gangguan metabolisme lipid (Wang et al., 2014). Trigliserida seharusnya digunakan sebagai sumber energi untuk beraktivitas (Muruganandan et al., 2005; Rini, 2012). Namun dengan adanya gangguan metabolisme lipid, sumber energi untuk beraktivitas bersumber dari protein yang berasal dari asupan pakan (Hartoyo et al., 2011). Di sisi lain, asupan pakan yang mengandung nutrisi seperti asam amino, protein, dan vitamin dapat mempercepat penyembuhan luka (Karri et al., 2015). Jika cadangan protein seluruhnya digunakan sebagai sumber energi, protein dari asupan pakan tidak digunakan sebagai nutrisi dalam mempercepat penyembuhan luka. Oleh karena itu, percepatan penyembuhan luka yang terjadi pada hewan uji yang mengalami penyusutan BB sebagai tanda DM tipe I pada penelitian ini dipengaruhi oleh pemberian topikal fraksi daun binahong. Lambatnya penyembuhan luka tidak dipengaruhi oleh penurunan berat badan hewan uji.

\section{Pengaruh Pemberian Topikal FDB terhadap Proses Penyembuhan Luka \\ Penyembuhan luka secara makroskopis} terlihat dari berkurangnya diameter luka atau disebut dengan parameter persentase penutupan luka. Penyembuhan luka secara makroskopis di hari ke 10 paling baik terlihat pada kelompok dengan pemberian FADB 10\%, FHDB 10\%, dan FKDB 10\% masing-masing dengan nilai $\mathrm{PL}_{\%}$ sebesar $69,34 \pm 6,35 \%, \quad 67,14 \pm 6,23 \%$, dan $64,86 \pm 4,08 \%$ yang berbeda signifikan dengan kontrol negatif (PL\% sebesar 57,48 $2,75 \%$ ) yang hanya diberi aplikasi topikal biocream ${ }^{\circledR}$. Ketiga nilai tersebut juga lebih besar dari kontrol positif madecassol ${ }^{\circledR}$ (PL\% sebesar $53,33 \pm 5,77 \%$ ) dengan perbedaan yang signifikan $(\mathrm{p}<0,05)$ yang 
Tabel III. Proses penutupan luka yang dilihat dari pengurangan diameter luka hari ke 0 hingga ke 10 selama perlakuan

\begin{tabular}{|c|c|c|c|c|c|c|c|c|c|c|c|}
\hline \multirow{2}{*}{$\begin{array}{l}\text { Kelompok } \\
\text { Perlakuan }\end{array}$} & \multicolumn{11}{|c|}{ Hari Ke } \\
\hline & $\mathbf{0}$ & 1 & 2 & 3 & 4 & 5 & 6 & 7 & 8 & 9 & 10 \\
\hline Kontrol normal & & & & & 4 & 4 & 4 & \&: & 4 & 1 & \\
\hline Kontrol negatif & & & & & & & 8 & $\ell$ & 8 & t & 8 \\
\hline Kontrol positif & & & & & & & 8 & $\boldsymbol{N}$ & * & & \\
\hline FHDB 5\% & & & & & & & & 8 & & $\boldsymbol{l}$ & \\
\hline FHDB 10\% & (2) & & & & 8 & e & e & e. & 1 & A & $\alpha$ \\
\hline FKDB 5\% & & & & & & & & & - & & \\
\hline FKDB 10\% & & & & & & & & & & & \\
\hline FEADB 5\% & & & & & & & * & $\Leftrightarrow$ & c) & - & \\
\hline FEADB $10 \%$ & & & & & s) & & & & $a$ & , & \\
\hline FEDB 5\% & & & & & & & & & 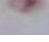 & ه & $\psi$ \\
\hline FEDB $10 \%$ & & & & & & 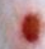 & & & a & * & \\
\hline FADB 5\% & & & & & 2 & & & 8 & 8 & 4 & (4) \\
\hline FADB $10 \%$ & & & & & & & & 8 & & a. & \\
\hline
\end{tabular}

Kelompok perlakuan: kontrol normal (non diabetes), kontrol negatif (diabetes + aplikasi topikal biocream $囚$ ), kontrol positif (diabetes + aplikasi topikal madecassol), aplikasi topikal 5 jenis fraksi daun binahong: FHDB (fraksi heksan), FKDB (fraksi kloroform), FEADB (fraksi etil asetat), FEDB (fraksi etanol), FADB (fraksi air) konsentrasi 5\% dan 10\% dengan basis biocream $®$.

menunjukkan potensi ketiga fraksi dibandingkan dengan kontrol positif. FADB $10 \%$ memiliki potensi tertinggi dalam mempercepat penutupan luka. Daun binahong mengandung banyak senyawa kimia polar, semi polar, dan non polar yang berperan dalam penyembuhan luka seperti tanin, saponin, alkaloid, steroid, triterpenoid, flavonoid, dan minyak atsiri (Ekaviantiwi, 2013). Senyawa tersebut berperan dalam penyembuhan luka (Ghosh and Gaba, 2013). FADB merupakan fraksi air daun binahong yang mengandung senyawa polar daun binahong. Madecassol ${ }^{\circledR}$ berasal dari ekstrak tanaman Centella asiatica (pegagan) yang mengandung zat aktif asiaticoside, madecassic acid, dan asiatic acid yang berperan dalam penyembuhan luka (Shukla et al., 1999). Binahong dan pegagan keduanya memiliki aktivitas sebagai antiinflamasi yang juga berperan dalam mekanisme penyembuhan luka (Sutrisno et al., 2016). 


\section{KESIMPULAN}

Percepatan penyembuhan luka yang secara makroskopis terlihat dari persentase penutupan luka dipengaruhi oleh penurunan kadar glukosa darah (KGD). Peningkatan KGD memperlambat penyembuhan luka. Penyusutan berat badan (BB) menjadi penanda terjadinya DM tipe 1 akibat induksi STZ $45 \mathrm{mg} / \mathrm{kgBB}$ i.p. dosis tunggal yang secara tidak langsung berkaitan dengan penyembuhan luka. Namun, adanya penurunan BB tidak mempengaruhi perlambatan penyembuhan luka. Fraksi air daun binahong 10\% (FADB 10\%) memiliki efek dan potensi tertinggi dalam mempercepat penutupan luka dibandingkan dengan kontrol negatif (biocream ${ }^{\circledR}$ ) dan kontrol positif (madecassol).

\section{UCAPAN TERIMAKASIH}

Penulis mengucapkan terimakasih kepada Ditjen DIKTI yang berperan dalam pembiayaan penelitian dan kepada seluruh anggota tim dan pihak-pihak yang telah terlibat dalam proses dan penyelesaian penelitian.

\section{DAFTAR PUSTAKA}

Anonim. 2014. Laporan Hasil Riset Kesehatan Dasar Indonesia (Riskesdas). 2013. Di Akses Di Http://http://www. Litbang. Depkes. Go. Id/sites/download/materi_pertemuan/ launch_riskesdas/Riskesdas 20.

Ariani, S. 2014. Khasiat Daun Binahong (Anredera cordifolia (Ten.) Steenis) terhadap Pembentukan Jaringan Granulasi dan Reepitelisasi Penyembuhan Luka Terbuka Kulit Kelinci. Jurnal E-Biomedik 1.

Ekaviantiwi, T. A. 2013. Identifikasi Asam Fenolat dari Ekstrak Etanol Daun Binahong (Anredera cordifolia (Ten.) Stennis) dan Uji Aktivitas Antioksidan. Chem Info Journal 1(1): 283-293.

Enoch, S. and Leaper, D.J. 2008. Basic science of wound healing. Surgery (Oxford). 26: 3137.

Furman, B. L., 2015, Streptozotocin-induced diabetic models in mice and rats, Current Protocols in Pharmacology. 5-47.

Ghasemi, A., Khalifi, S. and Jedi, S. 2014. Streptozotocin-nicotinamide-induced rat model of type 2 diabetes (review). Acta Physiologica Hungarica. 101: 408-420.

Ghosh, P.K. and Gaba, A. 2013. Phyto-extracts in wound healing. Journal of Pharmacy \& Pharmaceutical Sciences. 16: 760-820.

Hartoyo, A., Muchtadi, D., Astawan, M., Dahrulsyah and Winarto, A. 2011. Pengaruh Ekstrak
Protein Kacang Komak (Lablab purpureus (L.) Sweet) pada Kadar Glukosa dan Profil Lipida Serum Tikus Diabetes. J. Teknol. Dan Industri Pangan XXII.

Islas-Andrade, S., Monsalve, M. C. R., de la Peña, J. E., Polanco, A. C., Palomino, M. A. \& Velasco, A. F. 2001. Streptozotocin and alloxan in experimental diabetes: comparison of the two models in rats. Acta Histochemica et Cytochemica. 33(3): 201-208.

Jeffcoate, W.J. and Harding, K.G. 2003. Diabetic foot ulcers. The Lancet. 361: 1545-1551.

Karri, V.N.R., Kuppusamy, G., Mulukutla, S., Sood, S. and Malayandi, R. 2015. Understanding the implications of pharmaceutical excipients and additives in the treatment of diabetic foot ulcers. Journal of Excipients and Food Chemicals. 6: 7-22.

Kintoko \& Desmayanti, A. 2016. The effectivity of ethanolic extract of binahong leaves (Anredera cordifolia (tenore) steen) gel in the management of diabetic wound healing in aloxan-induced rat models. Jurnal Kedokteran Dan Kesehatan Indonesia. 7(5): 227-236.

Kolluru, G. K., Bir, S. C. \& Kevil, C. G. 2012. Endothelial dysfunction and diabetes: effects on angiogenesis, vascular remodeling, and wound healing. International Journal of Vascular Medicine 2012.

Leung, P.C. 2007. Diabetic foot ulcers-a comprehensive review. The Surgeon. 5: 219-231.

Mappa, T., Edy, H.J. and Kojong, N. 2013. Formulasi Gel Ekstrak Daun Sasaladahan (Peperomia pellucida (L.) HBK) dan Uji Efektivitasnya Terhadap Luka Bakar pada Kelinci (Oryctolagus Cuniculus). Pharmacon 2.

Morton, J.J. and Malone, M.H. 1972. Evaluation of vulneray activity by an open wound procedure in rats. Archives Internationales de Pharmacodynamie et de Therapie. 196: 117-126.

Muruganandan, S., Srinivasan, K., Gupta, S., Gupta, P.K. and Lal, J. 2005. Effect of mangiferin on hyperglycemia and atherogenicity in streptozotocin diabetic rats. Journal of Ethnopharmacology. 97: 497-501.

Nagori, B.P. and Solanki, R. 2011. Role of medicinal plants in wound healing. Research Journal of Medicinal Plant. 5: 392405.

Najafi, S. 2013. Phytochemical screening and antibacterial activity of leaf extract of Ziziphus mauritiana Lam. International 
Research Journal of Applied and Basic Sciences. 4: 3274-3276.

Nayak, B. Shivananda, Pereira, L. P. \& Maharaj, D. 2007. Wound healing activity of Carica papaya L. in experimentally induced diabetic rats. Indian Journal of Experimental Biology. 45(8): 739.

Patel, D. K., Kumar, R., Laloo, D. \& Hemalatha, S. 2012. Diabetes mellitus: an overview on its pharmacological aspects and reported medicinal plants having antidiabetic activity. Asian Pacific Journal of Tropical Biomedicine. 2(5): 411-420.

Rini, S. 2012. Pengaruh pemberian diet tinggi lemak terhadap kadar trigliserida pada tikus. PhD. Thesis, Universitas Muhammadiyah Surakarta.

Romero-Cerecero, O., Zamilpa, A., Díaz-García, E.R. and Tortoriello, J. 2014. Pharmacological effect of Ageratina pichinchensis on wound healing in diabetic rats and genotoxicity evaluation. Journal of Ethnopharmacology. 156: 222-227.

Sasidharan, S., Chen, Y., Saravanan, D., Sundram, K.M. and Latha, L.Y. 2011. Extraction, isolation and characterization of bioactive compounds from plants' extracts. African Journal of Traditional, Complementary and Alternative Medicines 8.

Shukla, A., Rasik, A. M., Jain, G. K., Shankar, R., Kulshrestha, D. K. \& Dhawan, B. N. 1999. In vitro and in vivo wound healing activity of asiaticoside isolated from Centella asiatica, Journal of Ethnopharmacology. 65(1): 1-11.

Srinivasan, K., Viswanad, B., Asrat, L., Kaul, C.L. and Ramarao, P. 2005. Combination of high-fat diet-fed and low-dose streptozotocin-treated rat: a model for type 2 diabetes and pharmacological screening. Pharmacological Research. 52: 313-320.

Sutrisno, E., I, K.A., Sukandar, E.Y., Fidrianny, I. and Aligita, W. 2016. Anti-Inflammatory Study of Anredera Cordifolia Leaves and Centella Asiatica Herbs and Its Combinations Using Human Red Blood Cell-Membrane Stabilization Method. Asian Journal of Pharmaceutical and Clinical Research. 0: 78-80.

Takahashi, M., Asikin, Y., Takara, K. and Wada, K. 2012. Screening of medicinal and edible plants in Okinawa, Japan, for enhanced proliferative and collagen synthesis activities in NB1RGB human skin fibroblast cells. Bioscience, Biotechnology, and Biochemistry. 76: 2317-2320.

Vidinskỳ, B., Gál, P., Toporcer, T., Longauer, F., Lenhardt, L., Bobrov, N. et al. 2006. Histological study of the first seven days of skin wound healing in rats. Acta Veterinaria Brno. 75(2): 197-202.

Wang, H., Li, H., Jiang, X., Shi, W., Shen, Z. and Li, M. 2014. Hepcidin Is Directly Regulated by Insulin and Plays an Important Role in Iron Overload in Streptozotocin-Induced Diabetic Rats. Diabetes. 63(5): 1506-1518.

Zychowska, M., Rojewska, E., Przewlocka, B. and Mika, J. 2013. Mechanisms and pharmacology of diabetic neuropathyexperimental and clinical studies. Pharmacological Reports. 65: 1601-1610. 